\title{
Oblicza religii Augusta Cieszkowskiego. Temporalny i dziejowy wymiar doświadczenia religijnego
} (Faces of Religion of August Cieszkowski. Temporal and Historical Dimension of Religious Experience)

\author{
MAREK SZULAKIEWICZ \\ Wydział Politologii i Studiów Międzynarodowych \\ Uniwersytet Mikołaja Kopernika \\ mszulak@uni.torun.pl
}

Streszczenie. August Cieszkowski należy do największych filozofów polskiej filozofii narodowej i filozofów dziejów. Był też myślicielem, w którego systemie filozoficznym religia odgrywała olbrzymią rolę. Nie byłoby tego systemu bez religii. W artykule ukazuje się rolę myślenia religijnego w całym systemie historiozoficznym Cieszkowskiego. Podkreśla się, że Cieszkowski jako filozof ponownie chciał „zaczarować rzeczywistość” i to wtedy, gdy rozwijająca się nauka intensywnie pracowała nad jej „odczarowaniem”. Jednak to „zaczarowanie” nie odbywało się w jego myśli „przeciwko nauce”. Odwrotnie: myśliciel z Wierzenicy znakomicie wykorzystywał osiągnięcia nauki, aby wskazać, że „religia jest wszystkim”. To, co „boskie”, nie jest już ulokowane w tajemniczym i oddzielnym sacrum, lecz stanowi nasze codzienne życie i działanie.

Stowa kluczowe: religia; czas; dzieje; doświadczenie; chrześcijaństwo.

Abctract. August Cieszkowski is one of the greatest philosophers of Polish philosophy of nation and history. He was also a thinker for whom religion played a formidable role in his philosophical system. If it had not been for religion, this system would not 
have existed at all. The present paper shows the importance of religious thinking in the whole historiosophical system of Cieszkowski. It underlines the fact that while the developing science was striving to "disenchant the world", Cieszkowski as a philosopher wanted to "enchant the reality" afresh. However, this "enchanting" was not being performed "against science". Quite to the contrary, this Polish thinker was employing scientific achievements to demonstrate that "religion is everything". Divinity is not placed in the mysterious and isolated sacred any more but constitutes our daily life and action.

Keywords: religion; time; history; experience; Christianity.

Sam czas doprowadza nas do nowego okresu świata, jak sam prąd morza doprowadził Kolumba do odkrycia nowej części świata, której się dopiero proroczo domyślat.

August Cieszkowski

Świadomość religijna człowieka określona jest tak wieloma czynnikami, a nasze doświadczenie świata ma tak wiele wymiarów, że próba unifikacji całego tego kompleksu z góry jest skazana na niepowodzenie. Często podkreśla się, że doświadczenie religijne jest to taka specyficzna treść naszej świadomości, która „umyka” naszemu poznaniu, oddana zaś władzy poznawczej zawsze traci swe (jakieś) podstawowe właściwości i ulega „mistyfikacji epistemologicznej”. Religia nie ma w takim ujęciu wartości poznawczej, ale i wartość poznawcza fałszuje religię. Rzadko przyjmuje się tezę E. Lévinasa, że „religia wie dużo więcej” (Levinas 1994, 152), raczej uznaje się, że „nie wie niczego". Ale jest też ujęcie drugie. W nim świadomość religijną chce się roztopić w całości naszych doświadczeń, odbierając jej odrębność, zaś samej religii pozbawiając miejsca w świecie, kapitulując przed tym, co „tu i teraz” i zapominając o tym, co nas „dotyczy bezwarunkowo” (Tillich). Henryk Elzenberg podkreślał, że religia i „doświadczenie religijne” to przede wszystkim „postawa religijna”, a nie racjonalny akt poznawczy, czy też system twierdzeń. W tej postawie chodzi o „zagęszczanie rzeczywistości”. Filozof ten pisał: „Religię definiowałbym jako tę postawę, którą człowiek przyjmuje po zerwaniu ze światem, zerwaniu pozytywnym, będącym zwróceniem się ku czemuś pozytywnemu, co «światem nie jest»” (Elzenberg 1986, 16). 
Jednak bez względu na przyjętą teorię, świadomość religijna jest „narzędziem” tego świata, w jakim człowiek spotyka się z „tym, co niewysłowione” (A. J. Heschel). Jest ona „skrojona na ludzką miarę” i dlatego nie wolno jej „wyrywać” z naturalnego otoczenia, w jakim żyje w codzienności dzisiejszego świata i kultury. Świadomość religijna i doświadczenie religijne jest zawsze „nasze, ludzkie”, a nie „boskie”. Nie jest nigdy „skostniałe i statyczne”, lecz zawsze „zmienne i elastyczne”. Nieustannie zmienia się i przybiera różną postać. Tezy tej nie osłabia również uznanie objawienia. Mówił bowiem N. Bierdiajew: „Objawienie zmienia człowieka, ale także jest zmieniane przez człowieka. Człowiek jest aktywny w przyjęciu objawienia” (Bierdiajew 1999, 89). Stąd też świadomość religijna i doświadczenie religijne nie jest subiektywnym stanem świadomości człowieka i nie może być rozważane jako taki stan, ale nie jest też „nadprzyrodzonym” stanem ducha. Chociaż doświadczenie takie jest zawsze osobiste, to jednak nie ogranicza się do tego, co „prywatne”; chociaż „jest własne”, to jednak nigdy nie jest egoistyczne. Doświadczenie religijne nie jest też obserwacyjnym i obiektywnym poznaniem Boga, lecz najpełniejszym uczestnictwem w świecie, ujawnianiem „Tego, co najważniejsze” i „Niewysłowione”. Dlatego religie są przede wszystkim antropologią: więcej w nich można się dowiedzieć o człowieku, niż o Bogu.

Jednak często dochodzi do sytuacji, gdy postawa religijna, w której jednostka „obcuje” z wartością i tym, co Niewysłowione, zostaje zobiektywizowana doktrynalnie i instytucjonalnie. Wtedy „doświadczenie religijne” staje się zjawiskiem kulturowym i podlega wpływom i relacjom epoki, określonej kultury i jej potrzeb. W tym kontekście łatwo stwierdzić, że doświadczenie takie jest określana przez wiele czynników: zależności społeczne, ducha epoki, potrzeby kulturowe itd. Świadomość i doświadczenie religijne nie da się oddzielić od świata, w jakim żyjemy: doświadczamy Boga na naszą, ludzką miarę. Kiedy porównamy na przykład (pozostając w obszarze naszej kultury) doświadczenie religijne człowieka z pierwszych wieków chrześcijaństwa, z takim doświadczeniem człowieka współczesnego, łatwo dostrzec, że warunkowane jest ono zupełnie innymi czynnikami. Tam, warunkowane było ono zbliżającym się eschatologicznym sądem Bożym, tu zaś, w kultu- 
rze współczesnej, wyrasta ono z pewnego zakłopotania człowieka współczesnego wobec nadprzyrodzoności. Biorąc to pod uwagę trzeba stwierdzić, że doświadczenie religijne chrześcijanina z pierwszego wieku było doświadczeniem chrześcijanina z pierwszego wieku, tak jak doświadczenie chrześcijanina z XXI wieku, jest z konieczności właśnie jego doświadczeniem religijnym, a nie tego pierwszego. I gdyby człowiek współczesny domagał się takiego samego doświadczenia religijnego, jakie miał człowiek pierwszego wieku, to by nie świadczyło to o absolutności tych doświadczeń, lecz raczej byłoby zwykłą ucieczką od współczesności. Stąd też zrozumienie religijności współczesnego człowieka (tak samo jak każdej epoki) wymaga poszukiwań warunków możliwości właśnie jego doświadczenia religijnego. Trzeba zawsze w takiej sytuacji zapytać o to, co je określa, jakie są podstawy tego doświadczenia w świecie współczesnym? Zacytujmy jeszcze raz Elzenberga: „Religia staje się niemoralna, gdy ma służyć zaspokojeniu potrzeb autocentrycznych, poręczać nieśmiertelność duszy, opatrzność, porządek moralny w świecie, panowanie sprawiedliwości” (Elzenberg 1963, 368). A jednak często tym się staje i to wtedy, gdy zostaje zobiektywizowana doktrynalnie i instytucjonalnie. Pisał J. Hick: „Formy, które przybiera świadomość boskości, są ludzkimi konstrukcjami stworzonymi z materiału zawierającego obrazowość przyjętą z tradycji religijnej, z życia każdej poszczególnej jednostki, jak i ogólnej psychologicznej struktury” (Hick 2005, 87).

Pytanie o „warunki możliwości” naszego doświadczenia religijnego i ludzkiej świadomości Transcendentnego, czy też „doświadczenia religijnego danej epoki” nie jest problemem nowym w filozofii religii. Wyrasta ono z ducha Kantowskiego, filozofii transcendentalnej i fenomenologii. Pisał K. Rahner: „Nasza mowa jest przedziwna i niesamowita, biorąc pod uwagę, że musimy mówić o Bogu w słowach przynależnych do naszego świata, gdyż innych nie posiadamy. [...] W ścisłym ujęciu, w teologicznej mowie jako takiej tym, kto jest obecny, nie jest Bóg, lecz my sami” (Rahner 2005, 234). W tym pytaniu uświadamiamy sobie, że różne tradycje religijne, doświadczenia epoki, wydarzenia i losy jednostek nie pozostają bez wpływu na ludzką/naszą świadomość Transcendentnego. Co prawda, zawsze pozostaje nadrzędne pytanie o to, czy jest ono doświadczaniem 
„poza nami”, czy też „wytworem naszej własnej świadomości”, lecz pytanie o warunki możliwości tego doświadczenia odnosi się do obu wymiarów tego nadrzędnego pytania. Biorąc pod uwagę zarówno ten Kantowski kontekst transcendentalny, jak i powyższe słowa Rahnera należy zapytać: jak w epoce Cieszkowskiego obecny był ten - jak mówi J. Hick - „piąty wymiar naszego doświadczenia” (Hick 2005, 256)1; ; jak uczestniczył w tym doświadczeniu sam Cieszkowski? I wreszcie: jak dzisiaj rozpoznajemy to, co boskie? Co dzisiaj określa doświadczenie religijne współczesnego człowieka? Czy można dostrzec jakąś przemianę i ewolucję warunków określających nasze doświadczenie religijne? I czy zmieniło się w tym względzie coś w porównaniu z „epoką Cieszkowskiego”? Nie chodzi przy tym o treść objawioną, lecz o historyczną formę jej urzeczywistnienia.

\section{Cieszkowski i religia}

Religia jest wszystkim dla wszystkich. August Cieszkowski

Nazwanie Cieszkowskiego „filozofem religii” nie byłoby właściwe. Z pewnością jest jednak myślicielem, w którego systemie filozoficznym religia ogrywa olbrzymią rolę, nawet więcej: nie byłoby tego systemu bez religii. W jego filozofii połączyły się „potok myśli, z potokiem religijnym” (Adam Żółtowski). Jest zatem z pewnością filozofem religijnym, i to tak bardzo, że nie stworzyłby swej filozofii bez religii. I chociaż z punktu widzenie prawowierności dogmatycznej Kościoła dzieła Cieszkowskiego nigdy nie były oceniane pozytywnie, odwrotnie: wielokrotnie wskazywano na ich „nieprawowierność”, oraz to, że miał „szaloną wiarę we własny rozum”, to jednak cały ten system spoczywa na idei bóstwa, Objawienia Chrystusa i „religii Ducha”. „Póki znano jedynie tom pierwszy dzieła Cieszkowskiego (1848) pisał I. Chrzanowski - dopóty jego filozofia nie była jeszcze dla wierzących

1 Pisze Hick: "Wszyscy stale doświadczamy trzech wymiarów przestrzeni i czwartego wymiaru czasu, ale piątego, duchowego wymiaru, doświadczają jedynie niektórzy i (w większości przypadków) tylko co jakiś czas” (Hick 2005, 256). 
katolików tak ciężkim kamieniem obrazy, jak później, w miarę ukazywania się dalszych tomów” (Chrzanowski 1922, 5). Elementów tej krytyki można znaleźć wiele. Dla jednych była bulwersująca pewność Cieszkowskiego, że został „wybrany na zwiastuna Bożych postanowień”. Wręcz obrazoburczo wołał bowiem sam Mistrz: „A jeżeliś mię wybrał Boże, na Zwiastuna wielkich postanowień Twoich, kieruj opatrznie słowy moimi, aby właściwe w duszy ludzkości uderzyły struny" (Cieszkowski 1923a, 304). W tej krytyce nie chodzi tylko o to, że filozof uznaje siebie za „wybranego" (to częste u filozofów!), lecz o to, że uznaje on sam siebie za myśliciela, którego Bóg powołał do objawienia ludzkości wielkiej myśli. I Cieszkowski niekiedy lęka się, że nie sprosta temu zadaniu. Woła na przykład: „Lecz gdyby to miało być dziełem zatracenia, - wstrzymaj raczej usta i pióro moje, i niech padnę ofiarą zuchwalstwa mojego - Poświęć mnie samego sprawiedliwemu gniewowi Twojemu, lecz nie dozwól, abym miał wspólników upadku" (Cieszkowski 1923a, 304). Ale obawy i krytykę Kościoła wzbudzały również te tezy (i przeświadczenie samego Cieszkowskiego), że dopiero on daje światu „objawienie Objawienia” (Cieszkowski 1923a, 394), czyli czyni to, co „nie udało się” Jezusowi Chrystusowi, zaś jego nauka wcale nie jest niższa niż nauczanie Jezusa Chrystusa. Pisał sam Cieszkowski: „Że objawienie to ostatecznym być jeszcze nie miało, to sam (Chrystus - MSz) uznał i wyrzekł, zapowiadając nastąpić mającego Ducha Pocieszyciela, który miał ludzkość we wszelką prawdę wprowadzić” (Cieszkowski 1923a, 26). Lecz najbardziej wstrząsające były tezy odnoszące się do samego Jezusa Chrystusa i Zbawienia. Pisał przykładowo Cieszkowski: „Objawienie się Chrystusa Mesjasza było koniecznym, zjawienie się Jezusa Nazareńskiego było przypadkowe; tamten być musiał, ten mógł być albo nie być, mógł być inny na jego miejscu, każdy Prorok, każdy Mąż, z którym był Bóg, mógł zostać Mesjaszem” (Cieszkowski 1923a, 398). A to znaczy, że filozof odkrywa i mocno akcentuje to, „że” Jezus „stał się” Chrystusem, i całkowitym „przypadkiem” było, że „to właśnie On nim się stał”. Ta droga religijnego rozumowania Cieszkowskiego z pewnością wykraczała poza epokę i dopiero dzisiaj, za sprawa np. R. Pannikara, znajduje ona dla siebie zielone światło. I nie należy się dziwić, że w XIX wieku spotkała się z ostrym sprzeciwem. 
Trzeba też stwierdzić, że „religijnie” system ten kształtował się w toku wielu przemian osobistego rozwoju Cieszkowskiego, ale i przeobrażeń epoki i filozofii niemieckiej, szczególnie „poheglowskiej”. I tu przemiany te nie ominęły zagadnień religijnych. Droga do tego, że Filozof uwierzył w to, że jest Parakletem, Duchem-Pocieszycielem (Cieszkowski 1923a, 370, 304), który objawia ludzkości przyszłość, była w jego rozwoju długa. Ale podkreślić należy też zdecydowany sąd o całym systemie Cieszkowskiego: „gdyby nie mocna wiara w Boga, jako nie sam rozum, ale także i miłość, w postęp moralny rodzaju ludzkiego i wzrost szczęścia na ziemi, i gdyby nie miłość ludzkości i ojczyzny, wyniki rozważań byłyby z pewnością inne” (Chrzanowski, 1922, 15). Jednak ten „element religijny” nie tylko „tkwi” głęboko w jego myśli. Dostrzec go można również w czymś, co określa całe filozofowanie Cieszkowskiego. Nie jest nim tylko „bycie filozofem” i uznawanie siebie „za filozofa”. Uznawał on siebie za „filozofa”, którego Bóg powołał do objawienia ludzkości wielkiej myśli, która „popchnie” ludzkość i świat ku czemuś ważnemu, co jest spełnieniem. Można powiedzieć, że Cieszkowski filozofuje i podejmuje „praktyczne działania” w wielu obszarach kultury jako „człowiek religijny” i z powodów religijnych. I czyni to bardzo mocno nie dbając o krytykę: „Szyderczy uśmiech występuje na usta wasze, i już otwieracie je, aby wypuścić pogardliwe słowo: Szaleństwo, słowo, którem przez wszystkie wieki piętnowano zrazu wszystko, co świętem jest. Lecz stójcie, - nie ważcie się nazywać szaleństwem tego, co tu słyszycie. [...] Zaprawdę, zaprawdę powiadamy Wam, nie jest to ani większe, ani mniejsze szaleństwo, niż to, które przed osiemnastą wiekami usłyszano, gdy po raz pierwszy odezwał się głos, wzywający ludzi do powszechnego Braterstwa” (Cieszkowski 1923a, 421). Wszystko jest teraz religią i doświadczeniem religijnym; nie ma, zostaje zlikwidowane, tradycyjne odróżnienie sacrum od profanum, religii od świeckości, działań religijnych od aktywności politycznej, społecznej czy ekonomicznej.

Trzeba zapytać: skąd taka uniwersalizacja religii? Dlaczego religia jest wszystkim? Cieszkowski otrzymał wczesną edukację w duchu kultury francuskiej, za sprawą baronowej de la Heye. Kultura francuska tamtego czasu nasiąknięta była krytycyzmem wobec tradycji i oświeceniową krytyką 
religii, zwłaszcza religii objawionej. To właśnie tam należy dostrzec idee prowadzące do załamania się potęgi pierwiastka religijnego i „odczarowania świata”. Skończoność wdziera się do ludzkiej świadomości a wraz z nią świat jest ograniczany tylko do „zmieniającej się materii”. Takie było „francuskie wychowanie”. Ale młody August dostrzegał też praktycznie, że francuskie idee „zmian na lepsze” przez odrzucenie tradycji i doświadczenia religijnego, i uznanie tego wszystkiego za „przeszkody” ku szczęściu i dobrobytu, nie przynoszą efektów. W przyszłości wiele z nich odrzuci, a do wielu doda też „idealistyczny pierwiastek niemiecki”. Z czym innym bowiem spotkał się po powrocie z Włoch, najpierw do Warszawy i później do Krakowa. Tu młody Cieszkowski spotyka się z próbą wykorzystania religii i religijnego wychowania nie tylko do budowania przeciwwagi do rewolucji społecznych, ale też do wzmocnienia polskości. Tu uczy się, że są ludzie, którzy obcują z boskością. Również za sprawą swego ojca (Pawła Cieszkowskiego), noszącego tytuł „hrabiego papieskiego”, uczony jest on poważnego traktowania religii i roli doświadczenia religijnego w naszym życiu. Zaś późniejsze dzieła filozoficzne stanowią ufilozoficznienie i uniwersalizację idei mesjanistycznych, dowodząc, że nie można uchwycić „ducha dziejów” bez religii i - dosadniej jeszcze - bez zrozumienia tego, czym jest chrześcijaństwo. Dosadnie filozof będzie mówił w „Ojcze nasz”, że świat oczekiwany nadejdzie dopiero „przez podniesienie stanu religijnego”, a zatem wcale nie przez zniszczenie i usunięcie, lecz „podniesienie do stanowiska powszechnego kapłaństwa ludzkości”. A zatem religia nie jest nigdy „sprawą prywatną”, w której może chodzić o „los jednostki”. Odwrotnie, jest ona zawsze sprawą uniwersalną, w której „chodzi o wszystko”, jest bowiem religia „duszą wszechświata”, „nerwem całego istnienia”, „spójnią społeczeństwa” (Cieszkowski 1923a, 443).

Cieszkowski chciał zrozumieć historię jako całość i wprowadzić swoistą ufność w przewidywalny tok dziejów. W tym poszukiwaniu „logiki dziejów” właśnie religia stanowi immanentną cechę tych przemian, bowiem - jak podkreśli - Bóg działa na świat, ale i świat działa na Boga (Cieszkowski 1923a, 506). Właśnie w religii Cieszkowski szukał metafizycznej podstawy logiki dziejów, i w niej też przejawiały się racjonalne i logiczne działania 
człowieka. To z religii doświadczył „trzeciej doby dziejów” (Cieszkowski 1923a, 131), to z religii i rozumienia Trójcy Świętej konstruował zasadę dziejową i przyszłe Królestwo Boże, to religia - wreszcie - przekształca czas w wieczność, przemijanie w trwanie, człowieka w „wolnego Ducha”. Wszystko to „dzieje się w religii” i „z religii”. Filozofia dziejów została nadbudowana nad religią i chrześcijaństwem, ale też dzieje są „naładowane" religią tak bardzo, że jeśli chce się "od wewnątrz" zrozumieć świat, to można to uczynić tylko przez religię i będąc religijnym. Poszukiwania wizji świata sensownego i optymistycznego odbywały się w jego filozofii właśnie przez religię, ale też religia miała odegrać w tej wizji ważną rolę. Bo religia zmienia się, ciągle przekształca się i przeradza: religia jest wieczna, lecz „nieruchoma być nie może” (Cieszkowski 1923a, 453). Dzieje nie były jedynie grą czynników psychicznych, politycznych i przypadkowych, lecz spełnianiem religijnego wymiaru istnienia. Cała historia jest objawieniem Trójcy Świętej. Osią dziejów ludzkości i sensem życia człowieka jest Jezus Chrystus. Właśnie doświadczenie religijne przynosiło przeświadczenie o jakimś ostatecznym porządku i ostatecznej mądrości realizowanej/ wypełnianej w dziejach świata. Ale również z religii (czy jeszcze dosadniej: w religii) ujawniało się zawsze zadanie do wypełnienia. Ów „czyn”, tak ważny w filozofii Cieszkowskiego, który „zmieniał świat i los człowieka” i który był „syntezą bytu i myśli” (Cieszkowski 1972, 14) nie był czymś niejasnym, lecz wynikał ze zrozumienia „religijnych losów świata”. Tkwi w tym religijne przekonanie, że świat nie jest koniecznością, lecz jest rezultatem czynu, nie musiał być, lecz jest. Bo właśnie religijnym pojmowaniem świata jest uznanie, że świat jest uzasadniony przez czyn, działanie Stwórcy. Człowiek musi się uczyć, planować i „przywoływać” to, czego jeszcze nie ma, a co z koniecznością „religijnego rozwoju” musi się „pojawić”. Nie powinien też czekać, co mu los przyniesie, lecz samemu określać, co mu ma przynieść. Ale musi też wiedzieć, że „coś” musi być dopiero, gdy przyszedł na to odpowiedni czas. I tak religijnie odczytany los świata realizowany jest przez „czyn człowieka”. Krocząc od przeczucia, przez świadomość religijną do czynu, człowiek staje na drodze przemiany świata i uczestniczenia w koniecznych, ale i dobrych przekształceniach, realizując „boski plan Opatrz- 
ności”. Rozróżnienie natury i historii, w której i człowiek „podejmuje swój czyn”, przebiega w obrębie dziejów, których sprawcą jest Bóg. Podejmując „swój czyn” człowiek ponosi odpowiedzialność za świat.

Lecz nie tylko „poważne traktowanie religii” określa jej obecność w filozofii Cieszkowskiego. Należy wspomnieć, że czas jego życia to kryzys „absolutnego idealizmu" i praca kultury i filozofii nad rehabilitacją empirii, natury i materii. Taka rehabilitacja po okresie „heglowskiego idealizmu” widoczna jest nie tylko w wielkiej filozofii Cieszkowskiego, ale również w jego działalności społeczno-politycznej, oświatowej i „praktycznie zmieniającej świat”. Nie był on filozofem gabinetowym, lecz „filozofem czynu”, który znakomicie rozumiał wartość świata. Dostrzegł wyraźnie i rozumiał, że wiek XIX „doszedł do świadomości organizacyjnej” i trzeba w organizacjach naukowych praktycznie wykorzystywać naukę do „zmiany rzeczywistości”. Taki sens miała jego działalność w Poznańskim Towarzystwie Przyjaciół Nauk, ale i konkretne podejmowane przez niego działania. Wystarczy tu wspomnieć o ochronach wiejskich, praktycznych sprawach ekonomicznych (system finansów, organizacja handlu drewnem) czy też organizacja szkoły rolniczej w Żabikowie. Wszystko to oznaczało, że na świat, materię, empirię przestaje się patrzyć przez idee „absolutnego idealizmu”, lecz dostrzega się wartość świata „tu i teraz”, świata, który da się, który można i który powinno się przemienić. Idealizm uznawał wprawdzie ducha, lecz go utożsamił z Duchem absolutnym. I to na nim, na procesie ewolucji Ducha absolutnego opierał się bieg świata. Właśnie z powodów religijnych Cieszkowski rehabilituje przyrodę, świat, materię: bez natury nie ma ducha (Cieszkowski 1972, 294). I to „podniesienie materii i konkretnego świata” ma w myśli Cieszkowskiego również aspekt religijny w uznawaniu, że byt skończony (czyli konkretny, materialny) nie różni się od nieskończonego Boga. Podstawą tej aktywności, „czynu w świecie” jest ontologiczny panenteizm i utożsamianie „świata z Bogiem”. Podkreślić tu trzeba, że znosi on dotychczasowy (poplatoński) chrześcijański ontologiczny dualizm i zastępuje monizmem, czy też - dosadnie mówiąc - panenteizmem (świat mieści się w Bogu). Cieszkowski w tym sensie często wskazuje, że za dni Chrystusa wystarczyło uwierzyć i ukochać, dzisiaj to za mało, trzeba działania, trzeba 
czynu. Jego praca jest pracą nad „przemianą materii i świata”. Żeby jednak ją podjąć, trzeba świat i materię traktować poważnie, nie jako zaprzeczenie Ducha, lecz jako „drogę Ducha”. Druga połowa wieku XIX odzyskuje sam świat, świat konkretny, który nie jest „przeciwko Bogu”, lecz „z Bogiem”. Podejmowaną przez wiek XIX filozoficzną chęć (i konieczność) odzyskania materii dostrzec można u Cieszkowskiego w koncepcji „poszukiwania pierwiastka materialnego w duchu”. Ale przejawia się ona również w uznaniu religijnej troski o cielesne potrzeby człowieka i działanie w kierunku „budowy” królestwa Bożego nie w zaświatach, lecz właśnie w świecie. Lecz najmocniej dostrzec ją można w podejmowaniu prób przełamania dualizmu i metafizycznym podziale na realny świat i idealny zaświat. Cieszkowski powie wyraźnie: „Dopóki stać będziemy jak wryci przy owym niedołężnym i niestosownym dla Ducha dualizmie realnego świata i idealnego zaświata, dopóty tkwić będziemy w sprzecznościach absolutnego rozdwojenia i dopóty też rzeczywistość wszelką tylko za marność poczytamy, a natomiast marom jakimś (abstrakcjom) hołdować będziemy” (Cieszkowski 1923b, 258). Paradoksalnie, człowiek tak głęboko religijny i z powodów religijnych znosi dualizm rzeczywistości, odzyskuje dla religii świat materialny jako „miejsce czynu" i realizacji Ducha.

Jako trzeci element, który określa miejsce religii w filozofii Cieszkowskiego, należy wskazać pewną nową jakość „mówienia o religii” w drugiej połowie XIX wieku. W tym czasie często zmierza się do wyrażenia religii nowym językiem i nowym sposobem myślenia, ale równie często wielcy filozofowie biorą chrześcijaństwo za przedmiot swej refleksji. Kultura zaczyna przemawiać faktami empirycznymi i historią, co wyraźnie widać również w decyzji Leona XIII, który otworzył uczonym archiwa watykańskie, umożliwiając nowy rozwój badań historycznych. Uzależnienie nauki Kościoła i religii od historii staje się coraz bardziej widoczne, co często też odbiera się jako relatywizm. W myśleniu o wierze i religii główny nacisk spoczywa teraz nie na tym, co subiektywne, osobiste i wewnętrzne, lecz na aspektach obiektywnych, zewnętrznych i historycznych. A te związane są z przemianą dziejów. Doświadczenie religijne zostaje wkomponowane w historię, dzieje i filozofię dziejów, zaś sama religia często zostaje uznana 
za najdonioślejszy składnik dziejów ludzkości. Starano się poradzić sobie ze swoistym napięciem pomiędzy przemijalnością wydarzeń historycznych a trwałą, pełną znaczenia „ideą”, która się w nich wyrażała. Koncepcja przemian dziejowych tego okresu prawie bezdyskusyjnie oznaczała uznanie jednokierunkowego biegu wydarzeń prowadzących do doskonalszych form. Pytania o prawo historii i czynniki sprawcze przemian dziejowych często napotykały właśnie religię. Łatwo zatem dostrzec, że doświadczenie religijne człowieka XIX wieku związane zostało z czasem i przemianą dziejów. Jednak i odwrotnie: odkryto, że na rzeczywistość, także historyczną, należy patrzeć również z perspektywy religii i wiary. Historia jest rezultatem działania ludzi, ale jednocześnie jest to „historia święta”, w której „realizuje się plan Boży”. Religia i wiara określają rozumienie dziejów, tego zatem, co nazywa się sensem istnienia człowieka i świata, a także kierunek rozwoju ludzkości ujmowanej jako byt historyczny. W polskiej historiozofii ujawnił się on z wielką mocą właśnie w myśli Augusta Cieszkowskiego. Bowiem myśl ta łączy religię, tradycję chrześcijańską z nowożytną filozofią dziejów, w której dostrzega się plan i kierunek dziejów. Myśliciel ten uznaje, że tylko religia może bronić oświecenia przed autodestrukcją. I tę obronę podejmuje swoją „religijną filozofią dziejów”. Ta obrona polega na tym, że „wszystko staje się religią”, wszystko, całe życie człowieka, jego działanie, jego czyn, a także życie narodów i kultur przesiąknięte zostaje religią. Można powiedzieć: jest tylko religia. Naturalnie nieokreślana przez Kościół, gdyż ten, jako odrębna instytucja, staje się niepotrzebny.

Ale Cieszkowski dostrzegał też swoisty błąd filozofii Hegla o religijnym znaczeniu. Polegał on na tym, że jego filozofia dziejów niezbyt doceniała doniosłość przyjścia Chrystusa i rolę „nowej religii” w integracji i rozwoju społeczeństw. Pisał Cieszkowski w Ojcze nasz: „,nowa religia będąca syntezą dotychczasowych wyznań religijnych (istna Religia, Religia sama, Religia przez się), która przyczyniać się będzie do usunięcia zła moralnego....Nie przychodzi ona rozwiązać Zakon, ale go wypełnić” (Cieszkowski 1923a, 89). Cieszkowski wierzył, że dopiero Chrystus powoduje oderwanie się człowieka od natury i daje jemu świadomość wyższego, nadziemskiego przeznaczenia. „Chrystus przyniósł światu element wewnętrzności, refleksji, 
subiektywności. Zmysłowość podniósł on do poziomu wewnętrznej świadomości, prawo - do poziomu moralności; stąd też Chrystus stanowi ośrodek czasów minionych, ponieważ On jeden radykalną reformę ludzkości spowodował i wielką kartę dziejów powszechnych obrócił" (Cieszkowski 1972, 18).

W ten sposób „wkomponował” Objawienie w dzieje, zaś zrozumienie dziejów oparł na Modlitwie Pańskiej. Cieszkowski rozumie religię jako więź, ale „pojęcie religii jako absolutnego związku Wszechświata, nie dla celu tylko bezpośrednio-widomego, doczesno-ograniczonego, przypadkowo-przyrodzonego, jak to w pogańskich społecznościach bywało, - ani też dla celu tylko idealno-pozaświatowego, wcale tu niewidomego, wiecznie tylko wiecznego, a więc nigdy doczesnego, obecnego (zawsze tylko transcendentnego, nigdy immanentnego), jaki w społeczeństwie chrześcijańskim panował, - ale dla istnego celu świata i Ludzkości, dla najwyższego dobra Ducha, w żywotnej i wszechobecnej rzeczywistości, które to dobro równie materialnego jak idealnego zadośćuczynienia wymaga” (Cieszkowski 1923b, 86). Podkreślał również pewną ewolucję „rozumienia Boga”. W epoce przedchrześcijańskiej, uznawano Boga za Byt Absolutny; w Chrześcijaństwie Bóg uczczony został jako Słowo wcielone, jako „suma wszystkich idealnych pierwiastków skupionych w osobie Chrystusa”. Lecz jest jeszcze jeden „szczebel” rozumienia Boga, „czas syntetycznego, czyli realnego pojęcia Boga, odkrycia Go w naszej świadomości takim, jakim jest we własnej osobie". W teorii Cieszkowskiego tym syntetycznym imieniem Boga, kojarzącym byt i myśl, materię i ideę, jest czynny Duch.

Takie temporalne spojrzenie na religię i jej miejsce w dziejach, ale również na doświadczenie religijne, przedstawia się jako doniosłe dla współczesności uhistorycznienie doświadczenia religijnego. Cieszkowski zespala ze sobą antropologię, dzieje i religię, czyniąc z nich wzajemnie umacniający się obszar działania, w którym człowiek buduje Królestwo Boże. I to właśnie religia, która nie jest oddzielona od świata, kultury, życia staje się „nerwem całego duchowego istnienia”, „duszą wszechświata”, „spójnią społeczeństwa”, „zamiast obumierać, religia dojrzewa, zamiast ujmy doznawać, wzrost swój ciągle świeci, zamiast ostatecznie niknąć, ostatecznie spełnia się" (Cieszkowski 1923b, 86). 


\section{Temporalizm kultury Zachodu a myśl religijna Cieszkowskiego}

Ignacy Chrzanowski określił Cieszkowskiego jako „do szpiku kości religijnego człowieka-chrześcijanina” (Chrzanowski 1922, 80). Jeśli chcemy jednak znaleźć podstawy takiego sądu, to łatwo dostrzec, że ani w jego życiu, ani tym bardziej w filozofii religijność nie polegała na tym tylko, że „był wyznawcą”, lecz na tym, że niezwykle szeroko pojmował „doświadczenie religijne" i jego podstawy. Nie wiązało się ono (jak się zwykle sądzi) z „przekraczaniem rzeczywistości” i skierowaniem ku „innemu światu”, lecz z działalnością i przemianą „tego świata”. Nikt inny w tej epoce, z tak wielką mocą jak właśnie Cieszkowski, nie rozumiał bezpośredniego zaangażowania w sprawy przemiany świata, aktywności i czynu jako „zadanie religijne”. Bo wszak - powie Cieszkowski - „czyn dopiero jest najwyższym, najświętszym celem Ducha. Czyn dopiero jest Bogu miłym. Czyn dopiero jest istną Miłością, Wyznaniem i czcią Boga” (Cieszkowski 1923b, 465).

Cieszkowski był filozofem religijnym, nie tylko w tym sensie, że religia była obecna w jego życiu, lecz jeszcze bardziej w sensie myśli filozoficznej. W życiu był Cieszkowski „praktykującym katolikiem” i niezwykle poważnie traktującym swą przynależność do Kościoła katolickiego. Żywo się też interesował samym nauczaniem Kościoła i jego przemianami: z wielkim zainteresowaniem osobiście śledził w Rzymie (1870) obrady I Soboru Watykańskiego, z wielką nadzieją przyjął też encyklikę społeczną Leona XIII Rerum novarum oraz „filozoficzną encyklikę” Aeterni Patris, zaś często publicznie przyznawał się do katolicyzmu. Jednak w całym jego systemie wyraża się nie tylko religijność i poważne potraktowania doświadczenia religijnego, lecz również temporalny wymiar kultury Zachodu, który w jego myśli zespolony został z doświadczeniem religijnym. Te dwa połączone elementy (religia i temporalizm) budują system filozoficzny Cieszkowskiego.

Powróćmy teraz do pytania o współczesny wymiar doświadczenia religijnego. Co dzisiaj określa doświadczenie religijne współczesnego człowieka? Czy można dostrzec jakąś przemianę i ewolucję warunków określających nasze doświadczenie religijne? I czy zmieniło się w tym względzie coś 
w porównaniu z „epoką Cieszkowskiego”? A może - w myśl jego tezy - po stu latach rzeczywiście „religia stała się wszystkim”?

Niewątpliwie inaczej niż w myśli Cieszkowskiego siedliskiem religii we współczesnej kulturze nie jest życie wspólnotowe, lecz doświadczenie indywidualne. Pisał przed laty Ch. Taylor: „Uderzającą cechą marszu Zachodu w stronę sekularyzmu jest to, że od samego początku marsz ten był spleciony z ciążeniem w kierunku religii osobistej” (Taylor 2002, 15). Z drugiej jednak strony z jeszcze większą mocą niż w „epoce Cieszkowskiego” doświadczenie religijne ujawnia swe odniesienie do czasu i historii. Łatwo dostrzec, że upływ czasu i świadomość historyczna budują dzisiaj określoną postać doświadczenia, w którym żyjemy, w tym również doświadczenia religijnego. $Z$ jednej strony, czas poddaje wszystko koniecznym przemianom i każe rozumieć świat w strukturach wariabilizmu i uznania, że „wszystko płynie”. Z drugiej zaś, „ożywia” i burzy schematy, ujawnia, że „wszystko może być inaczej”, „kategoryczność zamienia w hipotetyczność” itp. Pierwszy, relatywizujący charakter czasu, wydaje się pozostawać w sprzeczności z absolutnością i uniwersalnością doświadczenia religijnego. Ale również drugi aspekt - czasu, który 'otwiera nowe' - nie jest łatwy do uwzględnienia w świecie doświadczenia religijnego. Dzieje się tak z kilku powodów. Tam (w wariabilizmie) religia wydaje się tracić absolutność swych wypowiedzi, a właśnie tej absolutności człowiek domaga się w doświadczeniu religijnym. Tu zaś (w pragnieniu nowości) odbiera się jej skłonność do „posiadania ostatniego słowa” i to, że jest „stadium końcowym”, a tego właśnie żąda wyznawca jakiejś religii.

Można zatem powiedzieć, że człowiek kultury współczesnej odkrywa, że przestrzeń jest zbyt ciasna dla nieskończoności. Miejsce (przestrzeń) nie nosi już dzisiaj w sobie tajemnicy. Człowiek współczesny nie potrafi już poszukiwać „w różnych miejscach”. Można sądzić zatem, że jesteśmy w trakcie poszukiwań nowych warunków (wymiarów) doświadczenia religijnego, w którym „daleki Bóg” (w przestrzeni) stanie się na powrót „Bogiem z nami” (w czasie). To byłoby marzenie Cieszkowskiego. Czy czas może stać się warunkiem doświadczenia religijnego? Czy udaje się współczesnemu człowiekowi realizować postulaty Cieszkowskiego i połączyć an- 
tropologię, dzieje i religię w jedną filozoficzną całość? „Czas jest pojęciem, które oznacza, że nie wszystko zostało dane naraz, ale że stwarzanie nowej rzeczywistości dokonuje się w sposób stopniowy i nieustający, i że rzeczywistość jest w trakcie stawania się, kreowania krok po kroku” (Trasmontant 1996, 35).

Konieczność zmiany takich sposobów tematyzacji doświadczenia religijnego ujawnia się w naszych czasach szczególnie w nowej perspektywie patrzenia na świat. Najogólniej można to powiązać z degradacją przestrzeni i istnienia w naszej kulturze. Pisał Nietzsche: „I w tył, i w bok, i w przód, i we wszystkich kierunkach? Jestże jeszcze jakieś na dole i na górze?” (Nietzsche 1991, 165). Współczesna kultura przesiąknięta jest ideami „oddalania Boga”, w których Bóg staje się Bogiem obcym i dalekim. Niemożliwość przestrzennej organizacji świadomości religijnej oznacza stały wzrost tendencji do eliminacji nadprzyrodzoności i redukcję świata do „tu i teraz”. Na ten stan doświadczenia religijnego można patrzeć z zatroskaniem i lękiem. Ale można też zapytać, czy nie otwiera się w ten sposób dotychczas niewykorzystana szansa nowego doświadczenia religijnego, innej świadomości religijnej i innego mówienia o Bogu? Szansę taką stwarza czas i jego rosnąca rola w świadomości współczesnego człowieka. Trzeba zapytać: jeśli Bóg nie jest w stanie pojawić się dla współczesnego człowieka w kategoriach „blisko-daleko”, ,ponad światem”, jeśli nie ma już dla Niego „miejsca”, to czy nie należy odważnie zaangażować czas do świadomości religijnej i nauczyć się mówić o Bogu z naszego czasowego porządku istnienia, a zatem o „Bogu wczoraj”, „Bogu dzisiaj” i „Bogu jutra”?

\section{Czas i doświadczenie religijne dzisiaj}

Bo co spróchniało, to snać przeznaczenia swego dopełniło, co zwiędło i zeschło się, to na ogień dobre.

August Cieszkowski

Powtórzmy raz jeszcze za Cieszkowskim: religia nie obumiera, „owszem, dojrzewa, zamiast ujmy doznawać, wzrost swój ciągle święci, zamiast 
ostatecznie zniknąć, ostatecznie spełnia się”. Powtórzenie tej myśli jest szczególnie ważne we współczesnej kulturze. Na naszych oczach kultura odracza zmierzch religii i duchowości, i to odracza w nieskończoność. Kto śledzi problem „powrotu religii”, ten łatwo dostrzeże, że prace na ten temat stworzyły już pokaźną bibliotekę. Przede wszystkim niemiecki rynek wydawniczy, ale też anglojęzyczny, a również i polski prześcigają się w podkreślaniu tego ważnego już kulturowego zjawiska. Dyskutują na ten temat największe umysły i często staje się on swoistym kluczem do zrozumienia współczesnych wydarzeń w kulturze. Wydaje się już, że nie można zrozumieć naszego dzisiejszego świata bez powrotu religii i duchowości, i powrót ten zaczyna stawać się ponownie jakimś „kołem zamachowym” i nadzieją dla odzyskania energii dla naszej upadającej kultury. Nowym widmem, które zaczyna krążyć po Europie jest „widmo religii” (Nenning 1997, 9). Kulturowe spory czy nawet kłótnie coraz częściej mają charakter religijny i dotyczą jej obecności w sferze publicznej. Również w „nazwie” naszej epoki pojawiają się już pojęcia religijne: Habermas nazywa ją epoką „postsekularną”.

Jednocześnie, jeśli zwróci naszą uwagę świat religii, to łatwo dostrzec, że konkretne religie miały/mają , jakiś czas” (swój czas), lecz rzadko czas ten jest wewnętrzną ich cechą. Łatwo to zrozumieć. Czas był znakiem boskiej siły, bogowie byli zawsze we wszystkich przedziałach czasu, lecz sami czas „przekraczali” jako obecni w wieczności („Ty, Panie jesteś w wieczności...” - powie św. Augustyn) (św. Augustyn 1987, 271), w każdym czasie. Stąd też czas „zniekształcał” religie wprowadzając niemożliwe do zaakceptowania „odejmowanie” absolutności i równie niemożliwe do akceptacji dodawanie „nowości”. I chociaż teraźniejszość była jedynym czasem doświadczania świata, to religia swoje doświadczenia budowała zawsze na wieczności. Doświadczenie takie unikało świadomości historycznej widząc w niej największego wroga, który prowadzi do rozbicia absolutnych twierdzeń tradycji. Religijna wieczność często jest utożsamiana z nieobecnością czasu.

Jednak wewnętrzne zniekształcenie religii czasem jest do pomyślenia tylko tak długo, jak długo Bóg „pojawia” się w tym doświadczeniu jako Pan, Władca, Fundament, Strażnik..., jak długo utrzymuje się nieprzekraczalny 
dystans miedzy Bogiem a światem. Mówiąc inaczej, tylko w przestrzennie uwarunkowanym doświadczeniu religijnym czas jest jego destruktorem. Stwierdzał przed laty E. L. Mascall: „Dopuśćmy najdrobniejszy element czasu do pozaczasowości Boga, dopuśćmy najdrobniejszy element skończoności do nieskończoności Boga, dopuśćmy najdrobniejszy element zależności do samoistnienia Boga - a samo istnienie czasowego, skończonego i zależnego świata stanie się zarówno niewyjaśnialne, jak i niepoznawalne intelektualnie” (Mascall 1988, 211). Rzeczywiście, chciałoby się dodać: dopuszczenie czasu do doświadczenia religijnego zmienia wszystko. Jednak - jak mówiliśmy - we współczesnej kulturze rola czasu jest tak duża, że utrzymywanie nadal tej rozbieżności, pozostaje ze szkodą dla doświadczenia religijnego. To on właśnie, czas, staje się warunkiem doświadczania świata i często też warunkiem doświadczenia religijnego.

Trzeba zapytać: jak zmienia się to doświadczenie, gdy wśród jego warunków możliwości nie pojawia się przestrzeń, lecz czas? Spójrzmy tylko na kilka elementów uwarunkowanego przez czas doświadczenia religijnego.

Od „Bóg” do „Boże mój”. Karl Rahner w jednej z prac przedstawia szokującą hipotezę, w której „słowo Bóg znika bez śladu i bez reszty, nie pozostawiając żadnej widocznej luki, nie ustępuje miejsca żadnemu innemu słowu, które przemawiałoby do nas w ten sam sposób” (Rahner 1987, 45). Ta hipoteza byłaby - sądzi Rahner - katastrofą dla człowieka i świata, gdyż stałoby się wtedy coś przerażającego: oto człowiek utknąłby w świecie i w sobie. Przestałby być człowiekiem i powrócił do poziomu „pomysłowego zwierzęcia”. Można sądzić, że czas, który zaczyna odgrywać podstawową rolę we współczesnym doświadczeniu religijnym, wyznacza taką właśnie katastrofę dla religii i świata. Wiążąc religię z czasem wydaje się, że człowiek współczesny rzeczywiście „utknął w świecie”, nie potrafi już „przekraczać” świata, zajmuje się już tylko szczegółami swojego świata i sobą samym; jego świat i on sam staje się Bogiem.

A jednak pogląd ten nie jest słuszny, jeśli się zważy, że czas w doświadczeniu religijnym zmienia sposób odczuwania obecności Boga, o czym świetnie wiedział Cieszkowski. Rzeczywiście, zmienia się - i musi się zmienić obraz samego Boga: „tamten świat” zaczyna żyć w środku naszego życia, lecz 
nie jest wcale zredukowany do nicości. Zaś słowo Bóg nie znika wcale „bez śladu i bez reszty”. Zamiast mówienia o Bogu „w trzeciej osobie”, zamiast poszukiwań „transcendentnego Boga”, zamiast - wreszcie - Boga metafizycznego, czas sprawia, że w doświadczeniu religijnym Bóg obecny jest jako „znak nadziei tu i teraz”. Najlepiej można to wyrazić jako przejście od koncentracji na „Bóg”, ku życiu wierzącego z „Boże mój”, przejście od metafory „wysokości”, ku metaforze „głębi”. Bóg czasowo zorganizowanego doświadczenia religijnego jest Bogiem wiary, miłości i łaski, nie zaś transcendentnym uwieńczeniem wertykalnego porządku świata. Odkrywany jest w codziennym doświadczeniu, lecz naturalne jest, że odkrywany inaczej, niż jako Transcendencja będąca poza światem. Tę drogę najlepiej wyrazić właśnie słowami „Boże mój”: nie Kościołów, religii, teologów, lecz „mój tu i teraz”.

Zmiana doświadczenia religijnego z medium przestrzeni w medium czasu pozwala umocnić taką religijność, której elementem nie jest już „być lub nie być Boga” ani też pretensja o niedoskonałość świata, lecz w której Bóg pozostaje ważniejszy niż te dowody i ta postać świata. Na pytanie o istnienie Boga nie można odpowiedzieć „tak” lub „nie”: doświadczenie religijne jest teraz w stanie uwolnić się od metafizycznego problemu Boga. Zarówno w ukazywaniu transcendentnego wymiaru naszego życia, jak i doświadczenia religijnego omija się w ten sposób konieczność przejścia religii przez jakieś stanowisko metafizyczne: Bóg nie ingeruje w życie świata z zaświatów. Pisze L. Dupré: „Przez tysiąclecia ludzie uznawali transcendentny wymiar swego życia, nie dochodząc do złożonego pojęcia Boga” (Dupre 2003, 277). Czas osłabia taką religijność, w której rzeczywistość ma ukazywać obecność „czegoś innego”, będącego transcendentnym wobec świata, rozbudza z kolei taką religijność, w której „Bóg jest z nami”. I to dostrzec można w myśli Cieszkowskiego, i za to tez był krytykowany. Podstawą doświadczenia religijnego wyrażanego w medium czasu nie jest „coś innego”. Bóg nie oznacza „transcendentnego bytu”, lecz - możemy powiedzieć za współczesnym filozofem religii - „Bóg oznacza: Nikt nie jest nigdy sam” (Heschel 2001, 94). Nie jest to zatem odchodzenie od „tego, tu” do „jakiegoś tam”, od świata do „czegoś innego”, od „jednej danej” do „jakiejś innej danej”. Przeważnie milcząco wychodzi się z założenia, że istnieją dwa rodzaje 
doświadczeń, a to znaczy doświadczenie o charakterze religijnym (które ma coś wspólnego z Bogiem) i doświadczenie o charakterze świeckim (które jakoby nie mają nic wspólnego z Bogiem) (Imbach 1988, 32). Czas wskazuje jednak na konieczność przełamania takiego myślenia. W czasowo uwarunkowanym doświadczeniu religijnym musi się uznać, że to nie my wykorzystujemy „najwyższego”, „wszechmocnego” Boga do realizacji naszych spraw i rozwiązywaniu naszych problemów, lecz odwrotnie: to Bóg w czasie „używa” nas/mnie do swoich celów. Pisze B. Welte: „Do Boga czy do rzeczywistości, którą rozumieją przez słowo „Bóg”, ludzie odnoszą się najpierw w tym sensie, iż czują, że Bóg do nich przemawia i że zatem to właśnie Bóg jako pierwszy odnosi się do człowieka w obrębie odniesienia człowieka do Boga” (Welte 1996, 38). Jałowe jest poszukiwanie Boga w Jego istnieniu, w jego „jest”. Więcej nawet, choćby człowiek w jakiś sposób udowodnił Jego istnienie nadal może pozostać niewierzącym. Bowiem gdy człowiek rozpoznaje Boga przez rozumowe dowody, gdy szuka tych dowodów, aby utwierdzić się w Jego istnieniu (jako Transcendencji na zewnątrz), to już nie słyszy. Zaś efektem tych dowodów nie będzie wcale „mówiący Bóg”, lecz „Transcendentny Byt”.

Od „istnienia” do „słuchania”. Abraham J. Heschel często podkreślał, że religie są winne grzechu pychy i poczucia wyższości. Niosą przekonanie o własnej pewności, nieomylności, lecz przede wszystkim dowodzą, że „wiara to przywilej wyłącznie tych, którzy przebyli drogę, a nie tych, którzy są w drodze” (Heschel, 2005, 42). Łatwo dostrzec, że doświadczenie religijne związane z czasem zmienia ten stan rzeczy. Wiara wskazuje teraz właśnie na tych (nas wszystkich!), którzy „są w drodze”. Dostrzec czas „w” religii i religii wymaga odwrócenia błędu rozpoczynania od nas samych i naszych potrzeb. Religia przestaje być wyrazem spełnienia tych potrzeb, to raczej sposób, w jaki Bóg szuka, „wzywa” człowieka, zaś on sam musi „czekać”, słuchać i odpowiadać, czy tez - mówią językiem Cieszkowskiego - „musi czynić/działać”. Jego religia musi nosić w sobie wspomnienie, postrzeżenie i oczekiwanie, nie ma natomiast żadnej pewności i żadnej nieomylności. Uwzględnienie czasu w doświadczeniu religijnym oznacza, że człowiek jest wzywany zawsze na jego (człowieka) miarę. I nie może być inaczej. Dlatego 
religia jest teraz „sprawą Boga”, ale realizowaną przez człowieka; w religie zawsze jest zaangażowany czas. Objawienie jest zawsze uwikłane w okoliczności czasu. Medium czasu jest niezbędnym elementem w tym procesie. Szukanie człowieka przez Boga istnieje zawsze wyłącznie w spotkaniu z historią, kondycją intelektualną człowieka, jego wolą, możliwościami itp. Odbywa się zawsze w socjokulturowej i indywidualnej sytuacji człowieka (jednostki), w naszym ograniczeniu czasem. Można powiedzieć, że odpowiadamy na to szukanie (wezwanie) zawsze w naszych, ludzkich słowach. I też nie może być inaczej. Objawia i wzywa Bóg - odpowiada i rozumie człowiek. Dlatego tam właśnie, w religii i w stosunku do niej, człowiek najlepiej ujawnia to, kim jest i jaki jest: musi odpowiedzieć i musi uczynić to sam. Nie istnieje bardziej indywidualny wymiar życia człowieka niż wymiar religijny. Do człowieka należy bowiem zawsze znalezienie „sposobu” odpowiedzi na to wezwanie.

W konsekwencji takiego myślenia o religii (religiach), jako „odpowiedzi na wezwanie w czasie”, okazuje się, że mamy tu do spełnienia ważne zadanie. Jest to zadanie utrzymywania „otwartości religii”, zarówno na przeszłe (spełnione) religie, czyli takie, w których człowiek już „nie potrafi odpowiadać”, ale otwartości również na takie, w które przemienią się nasze dzisiejsze „odpowiedzi”. Czas „zabrania” ograniczać (zamykać) doświadczenie religijne zarówno w przeszłość, jak i w przyszłość. Stąd też w dawnych (martwych dzisiaj religiach) nie ma nic śmiesznego i godnego pogardy. Przy całej naszej (ludzkiej) „śmieszności” był tam też zawsze Bóg szukający człowieka i nawet te „śmieszności” nie przyćmiewały całkowicie światła, jakie było w nich obecne. To samo dotyczy przemian religii i nowych oczekiwań. Uwzględniając czas w doświadczeniu religijnym, nie można się zgodzić na uznawanie „statyczności”, niezmienności, wieczności panujących religii. Razem z nami religia rozwija się ku „większej pełni”, zmieniając sposoby wyrażania, ujawniając nowe aspekty wiary itd. Wszędzie są to tylko różne odpowiedzi na te same wezwania i często wspólne wysiłki człowieka w jego rozumieniu na miarę człowieka i miarę czasów. A zatem, zamiast rozważać religię hinduską, buddyzm, chrześcijaństwo... jako konkurencyjne i (każdą z osobna) jedyną drogę „ku Bogu”, spójrzmy na 
nie jako na „różne drogi” Boga do człowieka, jako różne odpowiedzi na te same wezwania w czasie. Zatem możemy powiedzieć, że włączenie czasu do doświadczenia religijnego współczesnego człowieka oznacza, że podmiot tego doświadczenia musi się stać religijny „od wewnątrz”. Czas wymaga życia wewnętrznego i osobistej odpowiedzi. Bóg lokalizuje się (jeśli tak można powiedzieć) w głębi naszego jestestwa i Jego „jest” oznacza „Boże mój”.

Od „nieśmiertelności” do „zmartwychwstania”. Epos o Gilgameszu poszukującym nieśmiertelności, jest wielkim przypomnieniem o tej potrzebie człowieka. Nieśmiertelność indywidualnej duszy, która ma cieszyć się w „innym świecie” niekończącym się szczęściem (lub niekończącą się niedolą), jest nierzadko obietnicą religii i ważnym wymiarem doświadczenia religijnego. Często w przeszłości religia przedstawiała się jako istotna dla kultury i człowieka z dwu powodów: gwarantowała porządek społeczny i/lub gwarantowała nieśmiertelność. Wynikała ona z nadziei na pomoc i interwencję w sprawach beznadziejnych. Nie trzeba dodawać, że w przestrzennie uwarunkowanym doświadczeniu religijnym idee te - szczególnie nieśmiertelności - stanowią jego centrum. Pojęcie nieśmiertelności zakorzenione jest w przestrzeni. Z kolei doświadczenie religijne uwarunkowane czasem odsyła ku innej idei: jest nią zmartwychwstanie. Trudno odnaleźć (i zrozumieć) zmartwychwstanie w przestrzennej organizacji tego doświadczenia. Za to łatwo zrozumieć nieśmiertelną duszę, która ma znaleźć się po śmierci „tam”, w „innym świecie”. Łatwo dostrzec, że czas umniejsza koncentrację na nieśmiertelności, czyniąc z nas „pasterzy bytu”. Dodajmy, że w chrześcijaństwie uznanie czasowego uwarunkowania doświadczenia religijnego oznacza przywrócenie (często wypartej przez idee nieśmiertelnej duszy) idei zmartwychwstania i wybór życia.

Jak łatwo zauważyć i ta krótka charakterystyka doświadczenia religijnego warunkowanego czasem nie wyczerpuje tematu. Trzeba jednak stwierdzić, że czas potwierdza transcendentny element w całym naszym życiu, we wszystkich związkach. Jednocześnie uniemożliwia wycofanie się z tego, co świeckie i przejście do tego, co „religijne”. Doświadczenie religijne tematyzowane czasem zaczyna się od wnętrza samego człowieka i staje się jego osobistą odpowiedzią. 


\section{Zakończenie}

Rozum musi wierzyćw Boga, żeby wierzyć w siebie.

Stanisław Brzozowski

Jeden z największych obrońców „wiary filozoficznej” Karl Jaspers, uprawiający swoją filozofię w Heidelbergu, mieście „doktoratu Cieszkowskiego”, podkreślał zagubienie i nieszczęście sytuacji, gdy nasza świadomość chce się „wyczerpać w samej rozumności” (Jaspers 2006, 215). Religia chroni naszą świadomość przed takim niebezpieczeństwem. Ale tylko taka religia, która żyje razem z nami, a nie taka, która chce żyć swoim życiem. Cieszkowski doskonale o tym wiedział. Mieszanie spraw ziemskich z nieziemskimi, marzenie o poprawie społecznej i jednocześnie o absolutnej epoce Ducha i spełnienie Objawienia, określają „religijne filozofowanie Cieszkowskiego”. Można powiedzieć, że Cieszkowski jako filozof ponownie chciał „zaczarować rzeczywistość”, i to wtedy, gdy rozwijająca się nauka intensywnie pracowała nad jej „odczarowaniem”. Co ciekawe jednak, to „zaczarowanie” nie odbywa się w jego myśli „przeciwko nauce”. Odwrotnie: myśliciel z Wierzenicy znakomicie wykorzystuje osiągnięcia nauki, aby wskazać, że „religia jest wszystkim”. To, co „boskie” nie jest już ulokowane w tajemniczym i oddzielnym sacrum, lecz stanowi nasze codzienne życie i działanie.

Na koniec trzeba jednak zapytać, co wynika z tego poważnego potraktowania czasu i historii/dziejów przez religie i jego uwzględnienie w doświadczeniu religijnym? Co z tego wynika dla współczesnego człowieka religijnego?

Łatwo dostrzec, że przestrzennie zorganizowane doświadczenie religijne orientuje się na pewną całościową wizję bytu, która jako zamknięta całość domaga się w swej strukturze transcendentnego Boga. W takim doświadczeniu mamy do czynienia z sacrum transcendentnym, zaś cały świat religii umacnia światopogląd nadnaturalistyczny. Inaczej jest w takim doświadczeniu religijnym, które organizowane jest przez czas. W nim świat jest „przesycony” świętością, sacralnością i mamy zawsze do czynienia z sacrum immanentnym. Dostrzec ten kierunek można w filozofii Cieszkowskiego, ale dostrzec można również w kulturze współczesnych 
przemian doświadczenia religijnego. Oczywiście również i dzisiaj (jak było to w czasach Cieszkowskiego) dostrzec można niedotrzymywanie kroku przez teologów tym wzorom myślenia, jakie panują w świecie. Sprawą najwyższej wagi jest tu nie tylko wykazanie, że wymiar religijny w istnieniu ludzkim nie ogranicza się do uznania istnienia Boga na sposób metafizyczny i podkreślania istnienia transcendentnego bytu. Sprawą najwyższej wagi jest wskazanie, że religia odsłania (ma odsłaniać) inny wymiar „tej rzeczywistości”, „tego świata”. Doświadczenie religijne nie jest obszarem, w którym człowiek religijny ma odkryć „tamten świat”, zaś religia ma wzbudzić marzenia o mitycznym raju i przy nich się zatrzymać. Jest zaś obszarem, w którym człowiek ma odkryć prawdziwy sens „tego świata”, „tej rzeczywistości”. Powtórzmy tu słowa D. Bonhoeffera, który prawie sto lat po Cieszkowskim wyraża jego filozofię jednym stwierdzeniem: „Chodzi o ten świat, a nie o tamten”. Temporalny wymiar doświadczenia religijnego oznacza, że Boga nie doświadcza się ponad światem i obok codziennych doświadczeń naszego życia, lecz w świecie i w codziennych doświadczeniach. Jedynie w temporalnym doświadczeniu religijnym człowiek rozumie, że chodzi właśnie o ten świat. Czas i zmiana nie tylko są wewnętrznie związane ze światem, ale też samo doświadczenie religijne nie jest bez nich możliwe. Religia i świadomość religijna nie jest zatem „skażona czasem”. Lecz właśnie odwrotnie: uwzględnienie czasu jeszcze mocniej umacnia w religii i teologii idee takiego Boga, który siebie wiąże z nami i światem, i którego doświadcza się nie obok codziennych spraw, lecz w nich. Wraz z czasem nie ma już pytania: „Gdzież jest Bóg”. Jest teraz pytanie: „Gdzież Go nie ma?”.

I jeszcze jeden element musi zwrócić naszą uwagę, który jest ważny dla człowieka religijnego i który mocno nawiązuje do myśli Cieszkowskiego. Doświadczenie religijne, w którym pomija się i neguje czas, jest też zawsze negacją wolności religii. Czas jako warunek doświadczenia religijnego zmusza do zmiany tego stanu rzeczy, łatwiej teraz dostrzec, że „religia nie była i nie będzie instytutem niewoli” (Cieszkowski 1923b, 447). Przymus i niewola w sferze religijnej jest teraz fundamentalnym naruszeniem natury wiary religijnej, doświadczenia religijnego i godności człowieka. Zarówno zmuszanie ludzi do tego, aby przyjmowali jakąś religię, jak i powstrzy- 
mywanie ich przed wyrażeniem swych przekonań religijnych, świadczy o fałszowaniu zjawiska religijności. Kto podejmuje się tego fałszowania, ten neguje to, że Bóg przyznał człowiekowi prawo do wolności i domaga się tej wolności najmocniej w sferze religijnej. Religia ma zawsze osobisty charakter wyrażany w czasie: wymaga wolności i czynu. „Religia jest i zawsze była związkiem, lecz nigdy więzieniem, stanowi ona węzły, nie zaś kajdany” (Cieszkowski 1923b, 446). Takie myślenie o religii coraz mocniej utwierdza się we współczesnej kulturze, prowadząc - jak chciał Cieszkowski - przez „kapłaństwo Ducha” ku „religii Ducha”.

\section{Bibliografia}

Augustyn, św. 1997. Wyznania. Warszawa: Znak.

Bierdiajew M. 1999. „Dwie wizje chrześcijaństwa. Spory o stare i nowe chrześcijaństwo.” In idem, Głoszę wolność. Wybór pism. Warszawa: Fundacja Aletheia. Chrzanowski I. 1922. Ojcze nasz Augusta Cieszkowskiego. Kraków: Nakładem Księgarni J. Czerneckiego.

Cieszkowski A. 1923a. Ojcze nasz, t. 2. Poznań: Fiszer i Majewski.

-. 1923b. Ojcze nasz, t. 3. Poznań: Fiszer i Majewski.

-. 1972. „Prolegomena do historiozofii.” In idem, Prolegomena do historiozofii. Bóg i palingeneza oraz mniejsze pisma filozoficzne z lat 1838-1842. Warszawa: PWN. Dupré L. 2003. Inny wymiar. Filozofia religii. Kraków: Znak.

Elzenberg H. 1963. Kłopot z istnieniem. Aforyzmy w porządku czasu. Toruń: Wydawnictwo Naukowe UMK.

Elzenberg H. 1986. „Motywacja etyczna (Wartość w religii i kulturze).” Studia Filozoficzne N 12 (233).

Heschel A. J. 2001. Człowiek nie jest sam. Filozofia religii. Kraków: Znak

-. 2005. „Żadna religia nie jest samotną wyspą.” In Abraham J. Heschel, Żadna religia nie jest samotna wyspa. Abraham Joshua Heschel i dialog międzyreligijny, red. H. Kasimow, B. L. Sherwin. Kraków: Znak.

Hick J. 2006. Piąty wymiar. Odkrywanie duchowego królestwa. Poznań: Zysk i S-ka.

Imbach J. 1988. Wiara z doświadczenia. O możliwości spotkania z Bogiem. Warszawa: Pax.

Jaspers K. 2006. O źródle i celu historii. Kęty: Marek Derewiecki.

Levinas E. 1994. O Bogu, który nawiedza myśl. Kraków: Znak. 
Mascall E. L. 1988. Otwartość bytu. Teologia naturalna dzisiaj. Warszawa: Pax.

Nenning G. 1997. Gott ist verrück. Zukunft der Religion. Düsseldorf: Patmos Verlag

Nietzsche F. 1991. Wiedza radosna. Warszawa: Jakub Mortkowicz.

Rahner K. 1987. Podstawowy wykład wiary. Wprowadzenie do pojęcia chrześcijaństwa. Warszawa: Pax

-. 2005. „Uwagi na temat nauki o Bogu w dogmatyce katolickiej.” In idem, Pisma wybrane, t. 1. Kraków: WAM.

Taylor C. 2002. Oblicza religii dzisiaj. Kraków: Znak.

Tresmontant C. 1996. Esej o myśli hebrajskiej. Kraków: Znak.

Welte B. 1996. Filozofia religii. Kraków: Znak. 